Reihe Politikwissenschaft Political Science Series

\title{
New Modes of Governance in Europe: Policy Making without Legislating?
}

Adrienne Héritier 

Reihe Politikwissenschaft Political Science Series

\section{New Modes of Governance in Europe: Policy Making without Legislating?}

Adrienne Héritier

March 2002

Institut für Höhere Studien (IHS), Wien Institute for Advanced Studies, Vienna 


\section{Contact:}

Prof. Dr. Adrienne Héritier

Max Planck Project Group

Common Goods: Law, Politics and Economics

Poppelsdorfer Allee 45

D-53115 Bonn

email: heritier@mpp-rdg.mpg.de

Founded in 1963 by two prominent Austrians living in exile - the sociologist Paul F. Lazarsfeld and the economist Oskar Morgenstern - with the financial support from the Ford Foundation, the Austrian Federal Ministry of Education, and the City of Vienna, the Institute for Advanced Studies (IHS) is the first institution for postgraduate education and research in economics and the social sciences in Austria. The Political Science Series presents research done at the Department of Political Science and aims to share "work in progress" before formal publication. It includes papers by the Department's teaching and research staff, visiting professors, graduate students, visiting fellows, and invited participants in seminars, workshops, and conferences. As usual, authors bear full responsibility for the content of their contributions.

Das Institut für Höhere Studien (IHS) wurde im Jahr 1963 von zwei prominenten Exilösterreichern dem Soziologen Paul F. Lazarsfeld und dem Ökonomen Oskar Morgenstern - mit Hilfe der FordStiftung, des Österreichischen Bundesministeriums für Unterricht und der Stadt Wien gegründet und ist somit die erste nachuniversitäre Lehr- und Forschungsstätte für die Sozial- und Wirtschaftswissenschaften in Österreich. Die Reihe Politikwissenschaft bietet Einblick in die Forschungsarbeit der Abteilung für Politikwissenschaft und verfolgt das Ziel, abteilungsinterne Diskussionsbeiträge einer breiteren fachinternen Öffentlichkeit zugänglich zu machen. Die inhaltliche Verantwortung für die veröffentlichten Beiträge liegt bei den Autoren und Autorinnen. Gastbeiträge werden als solche gekennzeichnet. 


\section{Abstract}

The article analyzes new modes of governance in Europe. Firstly, different types of new governance, the open coordination method and voluntary accords, and their individual elements are identified. The theoretical discussion about them points out the reasons of their emergence, their mode of operation and the links to the 'classical' forms of decision-making. Secondly the simple question of the relative importance of new modes of governance in European policy-making is raised. Looking at the policy measures from the beginning of 2000 until July 2001, the analysis found that only a minority of measures can be considered new modes of governance, defined in the above terms. A third question raised concerns political institutional capacity. Finally the question or instrumental capacity or effectiveness is raised. 


\section{Notes}

Adrienne Héritier was Visiting Professor at the Department of Political Science of the Institute for Advanced Studies in October 2001. 


\section{Contents}

1. Introduction 1

2. New Modes of Governance 3

2.1 Target Development: Implementation by Publication, Reputation Mechanisms, and Learning (Open Method of Coordination).............................................. 4

2.1.1 Target development and implementation by reputation mechanisms and

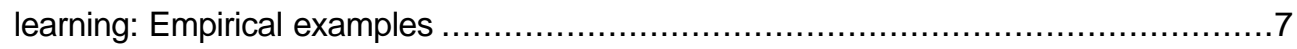

2.1.2 Discussion of political-institutional and instrumental capacity.................................

2.2 Target Development and Implementation by Voluntary Accords .............................. 10

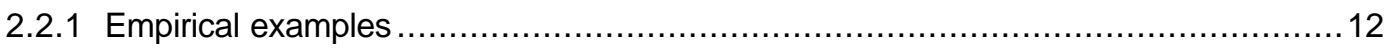

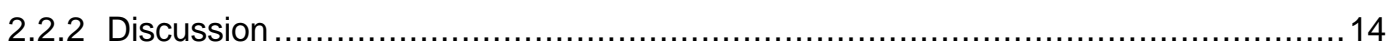

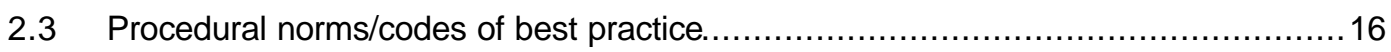



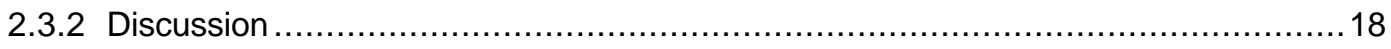

$\begin{array}{lr}\text { 3. Conclusions } & 18\end{array}$

$\begin{array}{lr}\text { 4. References } & 21\end{array}$ 



\section{Introduction}

Under conditions of problem interdependence across boundaries, collective action to provide common goods ${ }^{1}$ has to take place vertically across multiple levels of government and horizontally across multiple arenas ${ }^{2}$ involving public and private corporate actors. No single actor, public or private, has sufficient potential for action and/or sufficient power to solve problems of interdependence on her own, nor has she all the knowledge and information required to solve complex, dynamic, and diversified problems. Hence actors have to rely on each other (Kooiman 1993, 4). Problem interdependencies create incentives to cooperate: the very potential to mutually obstruct solutions promotes the willingness to come to agreements (van Vliet 1993, 110). Europe is such a multilevel and multi-arena polity, faced with complex problems of interdependence against a background of diverse social and economic conditions in which public and private actors with very diverse interests depend on each other to provide common goods. In short, it is faced with a need for governance across multiple arenas.

In the literature the concept of governance is used in two different ways: one broad, the other more restricted. In the encompassing sense it implies every mode of political steering involving public and private actors, including the traditional modes of government and different types of steering from hierarchical imposition to sheer information measures. In the restricted sense it only comprises types of political steering in which non-hierarchical modes of guidance, such as persuasion and negotiation, are employed, and/or public and private actors are engaged in policy formulation.

Private actors may be engaged in a variety of forms of policy formulation: ${ }^{3}$ they may "regulate" themselves on a voluntary basis; a regulatory task may have been delegated to them by a public actor; or they may be engaged in "co-regulation," regulating jointly with public actors. The focus of this analysis is on new modes of governance and government in the European Union that (a) include private actors in policy formulation, and/or (b) while being based on public actors, (c) are only marginally based on legislation (these are hierarchical insofar as they are subject to a majority decision) or that are not based on legislation at all. In recent years non-legislative modes of policy-making and modes of governance including private actors in policy-formulation have gained in salience in

1 Common goods include: public goods, characterized by accessibility and non-rival consumption; common pool resources, characterized by accessibility and rival consumption; and club goods, characterized by limited access and rival consumption.

2 Since the term "arena," in contrast to the term "level," encompasses both the vertical and horizontal dimension, it is used as the more general term

3 In policy implementation, private actors are regularly involved in the realization of policy measures, since they frequently are important addressees of these measures, as ultimate target groups or as instrumental organizations needed to relaize the targets (Windhoff-Héritier). 
European policy-making, and they have been advocated as a panacea for speeding up European decision making, which has so often ended up in gridlocks (Héritier 1999). The European integration project has reached a stage where core areas of the welfare state such as employment policy, social policy, and education are directly affected. These are areas where member state political support is very difficult to gain (Jacobsson 2001). Hence a method of cooperation has been developed to avoid the classical form of legislation through directives and regulations; instead, it relies on the open method of coordination, that is, target development and published scoreboards of national performance, as measured by the policy objectives that have been agreed upon, as well as voluntary accords, that is, the selfregulation of private actors. Many statements praising the new modes of governance have come out of the Commission. To quote just two examples here: The sixth Environmental Action Program promises that "voluntary initiatives will certainly have a key role to play" in European environmental policy in the coming years (DG XI official, European Voice, 11-17 January 2001). Additionally, employment and social policy Commissioner Diamantopoulos now calls legislation an "outdated" form of policy-making and points to the need for voluntary agreements among social partners (European Voice, March 2001).

While the Commission sees the new modes of governance as offering a possibility to expand European policies in the face of national governments' resistance, member-state governments prefer them to legislation because they allow member states more autonomy in shaping policy. Trade associations support the new modes of policy-making because they have an important role in it. The European Parliament is more skeptical because it circumvents the Parliament's rights of co-decision.

The aim of this article is to raise the following issues regarding the "new" modes of multilevel/multi-arena governance: First, different types of new governance and their individual elements are identified. The theoretical discussion about them points out the reasons for their emergence, their mode of operation, and the links to the "classical" hierarchical forms of decision-making. Second, the new modes of governance that provide common goods - in European policy measures - are empirically examined for a certain period of time; they are also gauged, both according to their political-institutional and their instrumental capacity. And finally, another issue is raised: namely, how do these new modes of governance fit into the overall context of European government and governance across multiple arenas, and what are their implications for the European polity as such? 


\section{New Modes of Governance}

There has been an increase in the political salience of the new modes of governance (CEC White Paper), in particular, of target definitions, and the publications of performance, on the one hand, and of voluntary accords with and by private actors, on the other. These new modes of governance are guided by the principles of voluntarism (non-binding targets and the use of soft law), subsidiarity (measures are decided by member states), and inclusion (the actors concerned participate in governance). The mechanisms of governance are diffusion and learning, persuasion, standardization of knowledge about policies, repetition (iterative processes of monitoring and target readjustment are employed) and time management (setting of time-tables) (Jacobsson 2001, 11ff.)

These modes are thought to have specific advantages: They evade the lengthy, unwieldy, and cumbersome process of legislative decision-making. At the same time, the threat of legislation is used to increase the willingness of actors to act voluntarily. Since these new forms of governance avoid regulatory requirements, it is expected that they will meet with less political resistance from the decision-makers and the implementing actors alike. After all, the latter would have to carry the costs of regulation. At the substantive level the advantages are seen in the greater flexibility of the policy measures and the greater adaptability of those measures to a rapidly changing social, economic, and technological environment.

Two basic new modes of governance are distinguished here: The first type - including two subtypes - develops substantive targets. The first subtype seeks to reach these targets exclusively by using reputation mechanisms and mutual learning (the open method of coordination). The second subtype seeks to reach the targets by using voluntary accords. The second type only defines procedural norms. It does not specify substantive policy targets. Each type/subtype is itself composed of several elements. It seems analytically useful to distinguish between the instruments employed - that is the mechanism used in order to reach a particular policy goal - and the decision-making/participatory structure in which these instruments are defined and then applied.

Types

1. Target setting

$1.1 \quad$ Target setting $\quad+$

publication of performance monitoring scoreboards learning

$1.2 \quad$ Target setting $\quad+\quad$ voluntary accords

2. Procedural norms $+\quad$ voluntary accords (no subst. targets) 
The individual types are discussed against the background of all the empirical instances of the new modes of governance - as defined above - that were initiated, developed, and decided upon from January 2000 to July 2001. First, the number of new governance measures of this type are set in relation to measures in all policy areas, ${ }^{4}$ that is, Commission regulations, decisions, directives, and recommendations, Council conclusions, resolutions, regulations, decisions, common positions, and recommendations, EP and Council directives and decisions. Of course, these individual decisions are of very different scope and importance, something not grasped by a sheer quantitative comparison. A total of 926 measures have been counted on the basis of the monthly Official Journal summary in Agence Europe (January 2000 until July 2001); 99 of these measures can be strictly considered "new modes of governance" as defined above: Community action programs comprising a few but not all the elements of the Open Method of Coordination (OMC) and voluntary accords. ${ }^{5}$ Most of the new measures are to be found in the areas of social policy and environmental policy.

\subsection{Target Development: Implementation by Publication, Reputation Mechanisms, and Learning (Open Method of Coordination)}

The theoretical background for target development as a novel method of policy-making has been formulated in the literature on the exchange of information, monitoring, and learning and deliberation as well as the theory of policy diffusion and transfer (Radaelli 2000). The linking of target development with these mechanisms and processes is thought to be welladapted to collective problem solving under conditions of local and regional diversity and under conditions in which problems are volatile (Dorf and Sabel 1998, 314). Under the notion of a "deliberative polyarchy," problem-solving experience is pooled, and the diverse pragmatic solutions practiced by various political actors and their respective performances are compared; this may trigger a learning process that benefits all the participants, informing separate, independent decisions (Dorf and Sabel 1998, 321). Under a somewhat stricter view, a reputation mechanism (naming and shaming) may induce a behavioral change accommodating the desired policy goals. The tool of benchmarking, applied in assessing organizations, has played an important role in the development of this instrument. Benchmarking implies comparing how an organization performs relative to other organizations in view of a defined target. The targets can be defined and benchmarking can be initiated by an organization itself (bottom-up), or this can be imposed (top-down) (de la Porte et al. 2001). "It involves searching for best practices, organizational learning and continuous improvement in order to eliminate performance gaps" (de la Porte et al. 2001, 2)

4 Except in security and defense policy, enlargement policy, and trade policy with respect to third countries, as well as decisions related to European bodies and decision-making rules in European bodies.

5 About half of the 99 new modes measures are not fully developed, open methods of coordination or voluntary accords; in these cases, a target is formulated by a European body, and then applications for projects funds are solicited in order to realize these targets, or mere recommendations are formulated. 
In terms of different forms of control (hierarchy: command and control, competition/rivalry, design: contrived randomness and architecture), and community: (social control) (Baldwin, Scott, and Hood 1998; Scott 2001), benchmarking is based on a loose form of communitybased control (Scott 2001, 16).

With respect to decision-making costs, target setting and publicizing performance have the advantage of not requiring a lengthy formal decision-making process before reach a consensus can be reached in the first place; instead, information pooling may begin informally and spread step by step. However, if performance is to be seriously monitored and evaluated, targets have to be defined and measured clearly, and third-party administrative support is required. A further condition for effective functioning is that the individual participants be willing to provide the necessary information (Dorf and Sabel 1998, 338).

In a more encompassing and long-term view, a successful on-going exchange of information on practices may lead to transnational decentralized learning networks (de la Porte et al. 2001, 11). In Europe these possibilities have raised the expectation that the European polity, as such, might eventually turn into a "confederation of (learning) policy-networks" (Beresford Taylor 2000), or epistemic communities (Haas 1992) promoting "communicative rationality in practice" (Dryzek 1987, 437). Policy standards have been developed through consultation with member-state representatives. Such standards can be adapted to different institutional environments, legal and national contexts (Mosher 2000).

From these general considerations it may be expected that little political opposition will arise from actors who bear the implementation costs, if they are involved in target-definition, if the are free to choose the instruments to reach these targets, and if supranational implementation limits itself to publishing and comparing performance. The actors involved are quite willing to participate in the decision-making processes that shape the governmental instruments, as they are willing to politically support the introduction of the instruments. In other words, this mode of governance has a high political-institutional capacity: it is able to generate both participation and political support.

Similarly, the instrumental capacity is expected to be high, i.e. the involved actors have strong incentives to apply the proposed instruments and the instruments are likely to contribute to solving the problem at hand. For watching the performance of others will induce member states to step up their endeavors to reach the set targets, using reputational mechanisms and/or integrating similar successful practices.

In the European context, benchmarking - that is, target development, mutual information, and learning - have been introduced as "open methods of coordination" aimed at orienting member-state activities towards a specific policy target within set timetables. It started with the monetary union, Best Economic Policy Guidelines and, more recently, Social Europe that is, employment policy, income distribution, working time, social protection, education 
and life-long learning, social infrastructure, regional cohesion, poverty and social inclusion. Instruments applied to reach the policy targets are chosen by member-state governments. Indicators of achievement (benchmarking) and guidelines for action are formulated and defined by the responsible actors, i.e. member-state governments, on the basis of a Commission proposal. They are then evaluated by a permanent high-level committee of national civil servants and the Commission (Scharpf 2000, 25). The performance is measured by the specified indicators. Member states have to report annually on the actions taken to implement these guidelines. The reports are subsequently monitored by peer review, officials of member-state governments, and the Commission. The outcomes are published and ranked (scoreboards; hit lists). The monitoring committee and the Commission may then propose specific recommendations to the Council. By publicizing and exchanging information about different practices, it is hoped that processes of mutual learning among member states will be set in motion. A reputation mechanism is at work: and it is expected that those showing a poor performance will be shamed into performing better. To facilitate reaching the defined targets, in some instances European funds are offered to finance special measures. By providing information on and comparing the policy performances of individual member states, the Commission takes on the role as the adjudicator and assessor of member-state achievements (de la Porte et al. 2001, 11). This mode of governance in itself is not novel, but has been employed at the national level. However, its use in the European context, with its highly diverse national policy practices, does constitute a novelty.

Looking more specifically at the individual components of target development and benchmarking, the following elements emerge.

Table 1: Target development and benchmarking: implementation by publication / monitoring / learning

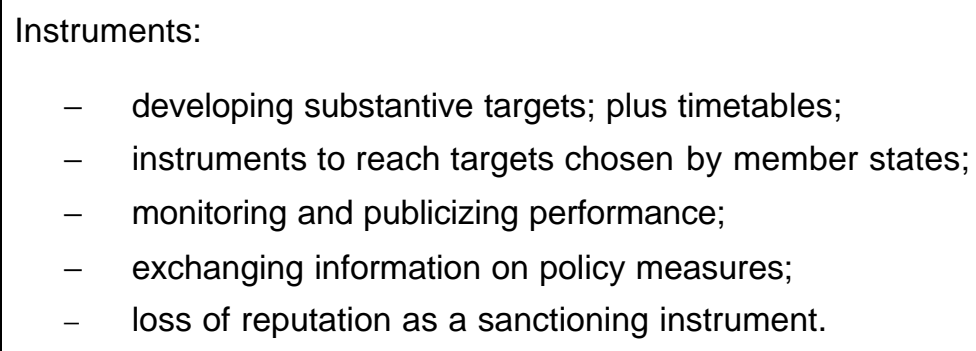

- developing substantive targets; plus timetables;

- instruments to reach targets chosen by member states;

- monitoring and publicizing performance;

- exchanging information on policy measures;

- loss of reputation as a sanctioning instrument.

Actor involvement and participatory structure:

- $\quad$ targets defined by private actors (self-regulation; peer review);

- targets defined by public actors;

- targets jointly defined by public and private actors (co-regulation). 


\subsubsection{Target development and implementation by reputation mechanisms and learning: Empirical examples}

From January 2000 till July 2001 target setting and monitoring as forms of open method of coordination linked with national action plans are to be found in the following measures:

In social policy:

- The "gender equality" program (2001-2005) provides for targets to be formulated to achieve gender equality in all community policies. Benchmarks will be used with clear criteria for assessing behavior; in addition, practices will be monitored, and all the programs will be evaluated (Agence Europe, Dec. 2000, 58).

- The "social services programme" has formulated indicators to measure social exclusion. More specifically, in health policy, targets have been defined by member states to reduce the waiting lists for the provision of health services. Transparency is to be established regarding the waiting times in the different national health systems.

- $\quad$ Under the "employment guidelines," labor market policies are to be evaluated according to quantitative and qualitative indicators. They are then to be subject to peer review. An exchange of information on good practices ought to initiate mutual learning (Agence Europe, June 2000, 13).

- An EP recommendation established a program in quality evaluation of school education (Official Journal, 1 March 2000).

- Educational benchmarks have been established, in particular for electronic learning (Agence Europe, May 2000). Member states' school systems will be measured in reference to these (Agence Europe, December 2000, 55-56).

- The draft regulation on "public interest services" provides a monitoring mechanism for public service performance. It is proposed that member-state governments report to the Commission every six months.

- A Youth Community Action Program has been established by the EP and the Council (Official Journal, 20 May 2000).

- A Community Action Program has been introduced to combat discrimination based on religion, sexual orientation, and age (Official Journal, 2 December 2000).

- A Decision of the EP and the Council introduced a training program for professionals in the European audiovisual program industry (Official Journal, 27 January 2001). 
- The Commission decided to monitor job satisfaction and stress levels as part of its annual evaluation of the Union's labor market (European Voice, 14-20 June 2001).

These measures are all examples of pure target development/benchmarking. Substantive targets are formulated by member states, the Commission taking part in the process. No particular instruments are recommended. Information is just exchanged on the performance and practices employed in member states.

Environmental policy is the second area in which examples of target setting and monitoring are found:

- Under the "safety at sea/maritime pollution" measure the Commission proposes banning all ships from EU ports that have been held in an EU port for safety checks twice in the last two years. A black list, which will be updated every six months, is to be set up to facilitate this (Agence Europe, March 2000 III, 54).

- In the "noise assessment" measure, noise indicators are to be developed which will make it possible for the member states to create noise cards and corresponding action plans to limit noise (Agence Europe, August/September 2000 III, 57).

- A pollutant emission register has been established under the Integrated Pollution Prevention and Control Directive.

- A Commission recommendation introduced monitoring levels of radioactivity to assess the exposure of the population (Official Journal, June 2000).

In contrast to the pure measures in social policy mentioned above, the environmental policy measures are mostly hybrids. They are closely linked to "hierarchy": in the case of the safety at sea measure, the scoreboard approach constitutes only one element in an otherwise straightforward regulatory command-and-control measure. The blacklist is to speed up safety checks; at the same time, it is a necessary precondition for banning ships. In the case of "noise assessment," the gathering and comparing of information is to be linked with action plans, which may subsequently lead to variable legislative measures, devised by member states.

Other measures:

- Ireland "was shamed" under the broad economic policy guidelines: The Council in February 2001 adopted a recommendation according to which Ireland "should end the inconsistency with the Broad Economic Policy Guidelines, engendered by the Budget Plans for 2001 to prevent a further boost to demand in Ireland aggravating overheating and inflationary pressure." The Commission will be mandated to monitor Ireland's 
economy on a monthly basis and report back to the Council during the course of 2000. Responding to the Recommendation, the Irish Finance Minister said that he had no intention of changing his economic policy and that Ireland's budget aimed to achieve economic stability with measures to curb wage increases, among others. The Economic and Monetary Affairs Commissioner was confident that Ireland would bow to pressure. However, there are no sanctions (Agence Europe, III February 2001, 14-15).

- The Commission recommendation of June 2000 was issued concerning the disclosure of information on financial instruments (Official Journal, 27 June 2000).

- The Commission initiated an Action Plan "Europe," supported by member states at the dotcom summit in Lisbon to accelerate the hternet penetration of schools (European Voice, 3 May-6 June 2001).

\subsubsection{Discussion of political-institutional and instrumental capacity}

On the basis of the general discussion, I concluded that the political-institutional capacity is expected to be high, that is, the willingness of involved actors to participate in a decisionmaking process that shapes the instrument and to politically support the introduction of the instrument. In the context of target development/monitoring, publication, scoreboards, and learning, member states are free to define and adopt their own measures for reaching the set target. The defined goals are not mandatory in the strict sense, and non-performance does not lead to formal sanctions. Hence low costs are expected for political decisionmaking; that is, it is expected that political support can be easily mustered up. There is a great willingness to take part in target definition, and the process is not long and drawn out. Because of the voluntary commitment, the instrumental institutional capacity is also expected to be high. While this may hold in general, a closer look at the political background of the development of some of the individual empirical cases reveals that this is not true under all circumstances. Rather, in social policy-making, target formulations have been very contested when attempts have been made to precisely define goals (de la Porte et al. 2001, 9). For instance, while the Commission is only too happy to start up a scoreboard with well-defined and measurable objectives, which will allow it to regularly monitor how much progress has been made in implementing the social agenda, member-state governments do not want clear targets to be set, which will make it possible to measure progress (European Voice, May 317 June 2000, 7). Instead, they prefer for target formulation to remain rather vague, in particular when the member states are pursuing conflicting goals and individual participants are tempted to free ride and not to contribute to the provision of common goods. Thus the employment goals decided upon at the Lisbon summit in 2000 - that is, "lifelong learning," "increasing employment in services," "modernizing social protection," and "promoting social inclusion" (Scharpf 2000, 25, footnote 20) - are rather fuzzy. Yet, there is also some indication that the pressure resulting from European measures - as soft as these may be - 
may help overcome domestic resistance to starting the reform of some institutionally deeply entrenched policies. Thus, in view of stalled domestic decision-making processes, some countries welcome the Commission initiative on the exchange of information about the functioning of old-age pension systems (von Maydell 2001). ${ }^{6}$

Of course, the mode of target formulation relates directly to the instrumental capacity, the extent to which incentives for implementation can be set, and the instrument's likely contribution to solving the problem at hand. Vague targets make monitoring, combined with voluntariness and the choice of instruments, a duller weapon than was originally planned (Beresford Taylor 2000, 21). National action plans may merely report on the on-going activities, without moving in new directions. In particular, when policy traditions are deeply embedded in institutions, such as those typically found in the national welfare-state practices, or when redistributive issues are at stake in dealing with the question of who contributes how much to the provision of a common good, there is a rather limited willingness to learn from member states with other practices. Learning seems to be restricted to minor points among countries with basically similar systems (Scharpf 2000) and/or to problems of a coordinative nature where all stand to win from providing the common good.

Viewing, in general, the development of European policy-making, social policy has been notoriously resistant to the influence of Europeanization. Against this background, the significance of target setting and publication is presently difficult to gauge. Only over a longer time period will it be possible to say whether it is only a first step, meant to prepare the ground for European legislative policy-making - the Commission's "foot in the door," as it were - in an area of policy-making which has thus far been jealously guarded by member states, or whether it is a new policy mode in its own right that will remain in place. The particular character of the link to "hierarchy" in the individual policy measures may throw some light on this question: where a measure is explicitly under the proviso that a legislative proposal will follow should the measure fail, it is likely that the measure is a first step towards legislation.

\subsection{Target Development and Implementation by Voluntary Accords}

Instead of just publishing performance data and exchanging information on policy practices, voluntary accords may be set up by the involved public and private actors to reach the specified targets. Co-regulation and self-regulation may have different origins and take on different forms: when private organizations establish and manage their own rules without outside interference, voluntary self-regulation (unilateral and negotiated agreements Lévêque 1998) has emerged. Delegated self-regulation, by contrast, is an arrangement 
imposed on private organizations, and the rules under which it functions are defined by a public authority (public voluntary agreements - Lévêque 1998; Ronit and Schneider 2000 23). Some voluntary accords function entirely independently; typically, targets are set in a collective decision process, and the industry is held collectively liable for implementation. In case of policy failure, the industry is collectively sanctioned, independently from individual firms' efforts (DeClercq et al. 2001, 19). Others function in the shadow of hierarchy and fulfill a "support function" (DeClercq et al. 2001, 19); that is, should there be mismanagement or policy failure, public authorities may take on the regulatory functions. They are instituted on a parallel private and public basis.

The theoretical discussion of voluntary accords points to various advantages that they have as steering instruments: For one, from the vantage point of political-institutional capacity, a voluntary commitment to an accord by a private actor implies lower political decision-making costs, because the affected private actors and their associations will mobilize less political resistance than they would in a legislative procedure. Another important advantage is that private accords may be reached more quickly, particularly if - given problem interdependence - there is a need to act across national boundaries and across governmental levels, where public decision-making is notoriously slow. Additionally, in terms of instrumental capacity, once commitment is secured, compliance is more likely both because private actors have participated in putting up the accord in the first place and may have developed an intrinsic motivation to carry it out (DeClercq et al. 2001, 16) and because they are better at mobilizing the necessary resources for implementation (Streeck and Schmitter 1985; Streeck 1995; Mayntz and Scharpf 1995). The private actors' resources cover a vast spectrum, ranging from the possibility of obliging members to comply with an accord ("Verpflichungsfähigkeit" or "governability" in the case of business associations) to financial resources, to technical expertise. Additionally, the interdependence between firms provides them both with extensive information about other market actors and with leverage to sanction non-compliance. All these elements help overcome the informational asymmetry between regulators and regulatees and prevent industry from an information closure (DeClercq et al. 2001, 16).

Why would private actors, for their part, be interested in committing themselves to such voluntary accords? At the political level, firms generally prefer voluntary agreements to legislation because such measures offer them more possibilities to shape the instruments used (Umweltgutachten 1998); indeed, by forming an institution under private authority, firms can influence public policies to their own advantage, more adjusted to the specific sectoral needs. They may also avoid some requirements associated with public authorities: for instance, the demands for accountability and the need to interact with other stakeholders (Cutler, Haufler, Porter 1999, 353). Such cooperative agreements also entail some advantages over strategies of non-cooperation with other private actors: they reduce transaction costs by providing information about other firms; they make it possible to more effectively cope with the problem of strategic interdependence by creating a commitment to 
joint activities; furthermore, such accords enhance the confidence of the industry's customers (Cutler, Haufler, Porter 1999, 352), environmental NGOs, and insurance companies (DeClercq et al. 2001, 16).

Voluntary accords to achieve specific policy targets may also be the frst initiate European policy-making in an area previously entirely reserved to member states. They have a "bridging or transition function" (DeClercq et al. 2001, 18) and constitute a stage preliminary to legislation (Sairinen and Teittinen 1999, 5; cited in DeClercq et al. 2001, 18).

The individual instrumental and decision-making components of this mode of governance are the following:

Table 2: $\quad$ Target development and implementation by voluntary accords

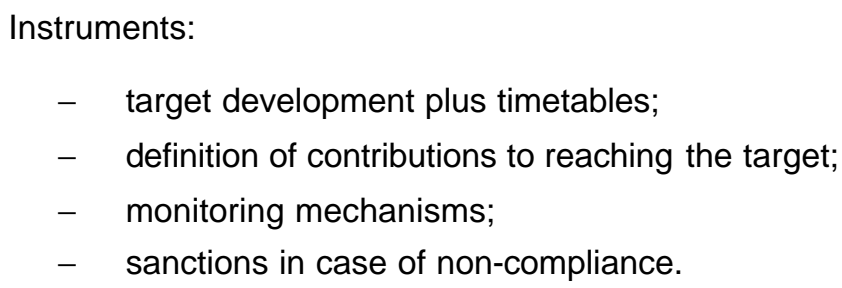

Actor involvement and participatory structure:

- $\quad$ targets and contributions set solely by private actors (self-regulation);

- $\quad$ targets and contributions set jointly by private and public actors (co-regulation).

\subsubsection{Empirical examples}

In environmental policy about 20 such accords are already in place (OECD 1999, 61). In the period under investigation, the following examples were found:

- The new "Sixth Environmental Action Programme," which the Commission agreed to at the end of January 2001, emphasizes the need for cooperation between industry, green groups, and national authorities when tackling major environmental problems. Wherever possible, voluntary agreements among various stakeholders are to be used rather than binding rules (European Voice, 11-17 January 2001, 6).

- Under the "energy efficiency programme," new voluntary agreements between the Commission and a number of industries are prepared $b$ boost the energy efficiency and to support the European Union climate-change strategy. Voluntary agreements with big industrial consumers such as the chemical, steal, pulp and paper, and cement and 
textile industries, are seen as making it possible to tailor mandatory energy efficiency objectives to the need(s) of the specific industry (Agence Europe, May 2000 III, 58).

- Minimum energy efficiency standards are also to be used more effectively by linking them with labeling schemes for certain products (household appliances, commercial and other end-use equipment).

- Another new voluntary accord is being prepared between the "automobile and oil industries" to reduce vehicle emissions. The first automobile-oil initiative was negotiated and set up in the beginning of the 1990s.

- Under the "road-safety programme," the Commission announced measures to make cars safer for pedestrians; the automobile industry announced that it is beginning work on a voluntary agreement. Here a deal is negotiated with the Commission to ensure the manufacture of safer vehicles with softer bumpers and low-impact metals. If this attempt at co-regulation fails, in which policy-makers set informal targets and leave it to industry to meet them, industry may be threatened with binding rules (European Voice, 14-20 June 2001). The Belgian Presidency is very critical of the voluntary code (a system testing the impact of a car in a collision with a pedestrian) and calls for binding rules in the form of a directive (European Voice, 28 June-4 July 2001).

- The "End-of-life Vehicles Directive" of 1999 proposes using voluntary agreements as an instrument to implement this in member states.

The other policy area in which both target setting and implementation by private accords are frequent is social policy. In the period under investigation the particular instances of new modes of governance are the following:

- Under "social dialogue," negotiations went on between social partners for nine months to hammer out a deal on the "working conditions for temporary staff" ("temps"). However, the negotiations quickly reached an impasse, and the deadline expired without a compromise being struck. Under Union rules it is expected that legislative steps will now be initiated by the Commission (European Voice, 8-14 March 2001, 8). While the European Trade Union Confederation, ETUC, demands that agency workers be treated the same way as their full-time counterparts, the European employers' association, UNICE, wants agencies to grant only minimum employment standards. UNICE also questions the EU's role in decision-making on this issue in the first place; it argues that this matter should not be decided by the Union's social partners, but by member states individually (European Voice, 4-10 January 2001, 6). However, Social Commissioner Diamantopoulos promised members of the European Parliament "firm action" - that is, legislation - should the negotiations stall (European Voice, 31 May-6 June 2001). 
- European airlines are presently negotiating an agreement to limit the flight time of pilots and crew. The EP has demanded that the agreement be integrated into a harmonized civil-aviation standard that incorporates technical requirements agreed upon by the aviation authorities. This standard is to be transposed into European Union law. However, for over a decade industry has failed to agree to modernized standards. If industry does not reach a deal, the EP will try to impose an agreement after the May deadline (European Voice, 11-17 January 2001, 3).

- In February 2001 the European social partners agreed to guidelines to grant teleworkers equal rights with other employees (Agence Europe, February 2001 III, 61; European Voice, 26 April-2 May 2001).

In both cases there is a clear link to hierarchy: that is, the Community is used to link control and hierarchy (Scott 2001, 11). In the case of "temps," legislation is planned should the social dialogue agreement fail. In the case of airline flight time regulation, a model of "encapsulated legislation" is provided for: the agreement reached is to be incorporated into a standard that regulates the industry. Then, by reference to the European legislation, it will be given a legal character. In some instances, from the very beginning, accords are meant to be incorporated into legislation after they are concluded (see also Falkner 2000, 1998).

Other measures:

- An anti-fraud program for non-cash payments has established a partnership between the payment-systems industry, retailers, infrastructure network providers, and national and international authorities. The Commission plans to organize a forum on technical security and will launch a fraud prevention webpage to encourage exchange of information between the payment industry and retailers (Agence Europe, February 2001 III, 23-24).

- A program to fight cyber crime has been introduced. An EU Forum with the participation of service providers, networks operators, consumer groups, data protection authorities, and representatives from law enforcement agencies, are to enhance cooperation and raise public awareness of risks (Agence Europe, February 2001 III, 70).

\subsubsection{Discussion}

While the popularity of these measures generally speaks for their political-institutional capacity - at least in comparison to the alternative of classical legislation - the de facto political institutional capacity is lower than has been claimed; that is, the costs for political decision-making are higher than theoretically anticipated. Several elements point to their possible costliness: For one thing, voluntary accords frequently have to be initiated by the 
Commission; that is, they would not emerge spontaneously. Further, industry, for its part, considers the Commission to have too much influence in shaping the guidelines and views the Commission as foisting requirements upon them, without allowing them a say (Chapman 2000 , 2). Additionally, if negotiations among private actors drag on and are long-winded, the accords are frequently linked to hierarchical decision-making. The participatory structure of the negotiations has given rise to criticism as well. Industry points to a bias in the participatory structure in the development of the regulatory arrangements. $\boldsymbol{h}$ its view that structure is selective and non-representative. For these reasons a formal review process at the EU level has been called for in which all sides - from industry, public interest groups, and government - are to have a voice (Chapman 2000, 2).

With respect to instrumental capacity, voluntary accords have met with criticism because legal certainty is considered to be unsatisfactory. Industry is split in its view: Some have leveled criticism because of the lack of legal certainty offered to those who are involved and the lack of accountability for the decisions made. In response to that, the Commission's environmental and legal-service officers have proposed drawing up a Union-wide regulatory framework before any new accords are struck. Such a framework, they argue, would give legal certainty to those involved; at the same time it would not detract from the flexibility or voluntary nature of such accords. This judicial framework for voluntary accords is supported by Members of Parliament, who point to the lack of accountability under private accords. Other representatives of industry argue, by contrast, that a legal framework would make it more difficult for them to join in such agreements (Cordes 2000, 2).

Seen in the overall context of European policy cevelopment, in using these new modes of governance, environmental policy and social policy come from different directions. In the past - that is in the 1980s and part of the 90s - environmental policy was an area of direct European intervention, of command-and-control legislation. Since the mid-90s, however, voluntary modes have increasingly been used. It was particularly under the pressure of Great Britain and the Netherlands that soft modes of environmental policy-making with legally non-binding targets were introduced (Héritier et al. 1996). The general direction of policy development, therefore, has shifted from hierarchy to self-regulation, ${ }^{7}$ with a "secondgeneration" of European policy instruments. However, the shadow of hierarchy still looms large when there is regulatory failure and when voluntary accords and public intervention mutually support one another. In social policy, by contrast, policy development shows a different pattern. Social policy has long been and in principle still is the exclusive territory of member states. Here, voluntary agreements constitute one of the first steps in European policy-making.

7 However, in some member states, such as Spain, where environmental policies did not play an important role before influence was wielded by the European Union, the direction of development is reversed. Here voluntary accord plays a role in familiarizing industry with environmental measures and enhancing compliance with national and European legislation (DeClercq et al. 2001:19). 


\subsection{Procedural norms/codes of best practice}

As opposed to target setting and implementation by monitoring and private accords, the new modes of governance that issue procedural norms or codes of best practice focus on how to properly deal with a problem or how to solve conflicts between participants, but they do not focus on specific substantive outcomes. Such codes might only be recommended; or they can be obligatory. Procedural norms may be backed up by a third party's authority (e.g. by the Commission or experts). In case of failure in the negotiation process or implementation failure, they may be followed by a legislative solution. Some procedural norms are formulated solely by industry.

In terms of political-institutional capacity, private actors have the same incentives to participate as they do in target setting linked with voluntary accords. Additionally, they should be motivated by the fact that no policy targets are imposed upon them. Moreover, in technologically complex areas, such activity also presents an opportunity to gain access to the expertise of competitors, that is, to gain knowledge about what those competitors are doing (Haufler 1999, 202). In terms of instrumental capacity, there are the same advantages as in the case of target-setting and voluntary accords: Commitment to such codes makes compliance more likely. They are considered to be more flexible and therefore adjustable to rapid technological and economic changes, and they are thus thought to fit better to the exigencies of a particular industry.

Procedural norms contain the following elements:

Table 3: $\quad$ Procedural norms / codes of best practice

Instruments:

- the instrumental element is identical with the procedure recommended.

Actor involvement and participatory structure:

- private actors only (self-regulation);

- private and public actors (co-regulation). 


\subsubsection{Empirical examples}

In the period under scrutiny, only four new procedural norms or codes of practice are found in the fields of social policy, environmental policy, and consumer policy.

In social policy:

- As a part of the social agenda, a high-level group of public actors has drawn up "best practice guidelines" for dealing with the problems of pensions. They have sought to encourage an exchange of ideas between countries on how to deal with the problem of the "social time bomb," and by doing so they monitor the success of individual governments' schemes.

- By urging companies to take on similar responsibilities for working conditions throughout Europe (in particular regarding the use of child labor), the Commission invites companies to formulate a code of conduct related to those issues for themselves. Should firms fail to do so, legislative steps will be taken (European Voice, 11-17 January 2001, 6).

Norms of organizational procedure are quite frequently to be found in environmental policy such as in the Eco-Audit and Management Regulation (EMAS) and the Seveso Directive and in product safety, where quality management systems are used (Spindler et al. 2000; Engel 1998).

- The EMAS scheme is presently being revised. In 1993 it was originally set up with the aim of establishing common standards for auditing the environmental aspects of the activities of industrial companies. The aim of the revision is to broaden the involvement in the scheme, particularly to include small and medium-sized industrial firms as well as non-industrial companies. Approved companies may use the EMAS logo. The EP now urges taking the informational needs of all stakeholders into account. It recalled an agreement with the Council stipulating that the environmental statements under EMAS were to consider the particular interests of all the relevant parties and that the information was to be presented in a clear and coherent manner in printed form. At least every three years the Commission is to report to the Parliament EP and the Council on the functioning of EMAS (Agence Europe, December 2000 III, 76).

Consumer policy applies voluntary codes of conduct, too:

- Under the guidelines of the Commission and member states, voluntary codes of conduct are to be established by Internet-based firms to boost consumer confidence. A core group of specially invited firms and consumers have been selected to discuss the details of the proposal. While consumer organizations have welcomed the step, larger 
industry groups have been critical of this "separate co-regulation scenario," developed by the Commissioner for consumer affairs.

\subsubsection{Discussion}

In terms of political-institutional capacity, the political decision-making costs necessary to bring a code about - for the above stated reasons - are expected to be lower. In the empirical cases under scrutiny here this has been the case only to a limited extent. In particular in the case of EMAS there was a long drawn out negotiation process between private and public actors in some countries, such as Germany, when the specific aspects of implementation were hammered out. This makes it clear that, even when no costs are involved with agreeing on a substantive policy target, there may be substantial costs connected with introducing and operating new institutions in order to apply the procedure (see the administrative resistance in the case of access to information in environmental policy - Bugdahn 2001).

The participatory structure under which such procedural codes are developed has also been heavily criticized by stakeholders for the imbalanced involvement of affected interests in the development of the instrument. In one instance (EMAS), industry is seen to be favored to the detriment of environmental associations. In consumer policy, too, the interest groups involved are considered to be selective and non-representative. To prevent this and to allow for the balanced involvement of the actors concerned, industrial associations call for formalizing the participation of the stakeholders, specifically by formulating the guidelines to be followed.

To increase the instrumental capacity, there is usually a link to hierarchy: specifically, there is parallel supervision by public authorities, among other things, to increase transparency in utilizing the instrument in case the privately established code should fail to function as expected. The shadow of hierarchy is criticized by industry as a Commission attempt to force guidelines upon it.

\section{Conclusions}

In this contribution four questions have been addressed regarding new modes of governance in Europe aimed at providing common goods. The first question raised the simple question of the relative importance of new modes of governance in European policymaking in view of the fundamental shift in the mode of policy-making. Looking at the policy measures from the beginning of 2000 until July 2001, the analysis found that only a minority of measures can be considered new modes of governance, defined in terms of target development, benchmarking, monitoring, voluntary accords, and codes of practices. Hence, 
the new modes are by no means on their way to becoming the predominant forms of European policy-making. The large majority of these measures are to be found in the areas of social and environmental policy. The new modes are of especially great importance in the area of employment and social policy.

After estimating the relative quantitative importance of the new types of governing and governance, the second question was raised: it concerned political institutional capacity. It is generally argued that target development linked with publicizing the participation of those bearing the costs of implementation increases their willingness to take part in shaping these instruments and reduces political opposition. Some evidence to that effect is provided: industries' quick acceptance of the open method of coordination, voluntary accords for environmental matters, and the greater frequency of such measures in social policy. The information gathered on the decision-making process involved in shaping new instruments show that it is not as insignificant as expected. Three aspects of the decision-making process point to this: First, member states involved in target development and private actors involved in setting up voluntary accords are frequently engaged in lengthy negotiations over the contents of these targets, preferring soft targets, while the Commission pushes for specific ones. Second, these "new" modes often need an element of "hierarchy" in order to be brought about in the first place; that is, they are either initiated and guided by the Commission, or when private actors lag behind in decision-making, the Commission, the Council, and the EP step in and proceed to legislation. Hence, in setting the right incentives for actors to sway them to participate in policy formulation, their political-institutional capacity is strongly linked with legislative policy-making. Thus, although the new modes of governance extensively rely on voluntariness and private actors, as is evident in the voluntary accords and codes of practices, these actors are moving around "on a leash," so to say Third, another type of "political cost" emerges which has not remained unchallenged, namely, a certain selectiveness in the institutional context of policy formulation in voluntary accords. Private actors have been voicing criticism of this because of the selective involvement of private actors in policy formulation. They advocate a regulatory framework to balance participation.

Effectiveness was the third issue raised, specifically the instrumental capacity of new modes of governance, defined as a congruence of the incentive structure of the instrument with the central implementing actors, on the one hand, and the capacity to the reach the defined policy target, on the other. On theoretical grounds, an enhanced instrumental capacity is expected because the actors bearing the costs of implementation have a say in shaping the policy instrument and are therefore willing to provide their expertise in that area and to commit the members of their organizations to implementation. The sources of information looked at here do not allow us to come to a systematic assessment of the quality of implementation and the effectiveness of the new modes. What has emerged about the particular structure of the new modes, however, is that they are frequently hybrids: the 
instrumental capacity of rew modes is often backed up by hierarchy," that is, the threat is voiced that traditional legislation will ensue if implementation should be unsatisfactory.

Also, there is an inherent conflict between targets that can easily be agreed upon, and carry few decision-making costs, on the one hand, and the effectiveness of those targets, on the other. If targets are formulated in a general way, which may make them politically easy to achieve, then they often have "no bite" when implemented, and they remain without much effect. Against this background it has also been pointed out that these soft instruments do not purvey legal certainty and that frequently there is a lack of accountability for the impact of applying these instruments.

In brief, viewing institutional and instrumental capacity on the basis of the empirical cases under scrutiny here indicates that, in order to fully deploy both capacities, the new modes of governance would have to rely on an entire "infrastructure” aimed at establishing the following conditions: the right incentives for those bearing the costs of regulation; the right participatory structure for shaping the instruments so that all those affected have a voice in shaping them; the guarantee of legal certainty; and the possibility to hold actors accountable for the consequences of particular actions. Hence, as easy as the new modes of governance may seem at first glance, when they are analyzed in detail it becomes clear that they are more demanding than expected.

Finally the question of the significance of the new modes in the overall context of the European polity has to be discussed. Two aspects help to put them into perspective: On a time scale, the role of target development, benchmarking, and monitoring has yet to be properly assessed. It may turn out not to be a new type of policy-making at all and that such mechanisms have long been employed when the Commission has sought to move into a new national policy area that has long proven to be particularly resistant to Europeanization. Hence we might also find it to be a first step on the way to European legislation.

At an overall political decision-making level, the attempt to push European policy-making forward by the open method of coordination and voluntary accords may be seen as a "third way" between supranationalism and intergovernmentalism, which is needed when moving into core areas of member states' policy-making (Jacobsson 2001, 2). It offers a possibility to overcome the "joint decision trap" (Scharpf 1999), i.e. that trap encountered by member states which desire a closer cooperation in social issues, but are not willing to embark upon supranational decision-making (Jacobsson 2001, 5; Streeck 1995). 
From the viewpoint of democratic legitimation, advantages and disadvantages of the open method of coordination exist, too: ${ }^{8}$ Members of the European Parliament view the process with some skepticism since they are not involved in this soft mode of policy-making, and they opt for legislation instead. Yet, at the same time, if the public is strongly involved in debating cross-national performance in the areas chosen for benchmarking and best practices, this could create a European policy space. It could also add political credibility and legitimacy to national policy-makers, since open coordination would lend itself to avenues that press for accountability from below and help improve "good governance" in Europe (de la Porte et al. 2001, 14-15). However, it may still be premature to advocate that the future of the European policy-making system ought to become "a confederation of learning networks" (Beresford Taylor 2000, 21), œntered around sharing knowledge and experience, and characterized by benchmarking, peer review, and public pressure.

\section{References}

Baldwin, R., C. Scott, and C. Hood. A Reader on Regulation. Oxford: Oxford University Press, 1998.

Beresford Taylor, A. "EU moves towards the creation of a network Europe". In: European Voice, 15-21.6.2000: 21.

Bugdahn, S. Freedom of Access to Information on the Environment: The EU Directive and its Implementation. Thesis Manuscript, European University Institute, Florence, 2001.

CEC European Governance: A White Paper, Brussels, July 2001.

Chapman, P. Industry Voices Concerns Over Co-Regulation". In: European Voice, 26.10.1.11.2000: 2.

Cordes, R. "Argument rages over voluntary energy-saving industry accords". In: European Voice, 4-10.5.2000: 2.

Cutler, C., Haufler, V., and Porter T. (eds.) Private Authority and International Affairs, New York: SUNY Press, 1999.

8 However, it is also contested: The Commission's employment General Directorate advocates these tools rather than legislation, considering the latter to be outdated and too slow in a fast moving economy. Yet, there is resistance from some member states, and in the specific case, from France. Its labor minister, for example, argues for more legislation in social policy. This position is supported by heads of governments at the subnational level in Germany (e.g. Wolfgang Clement) who are afraid that the new modes of governance will undermine their legal competences in shaping European policy-making. 
Declercq, M. et al. National Patterns in the Use of Voluntary Approaches in Environmental Policy, International Policy Workshop on the Use of Voluntary Approaches, 2001.

de la Porte, C., Ph. Pochet, and G. Room "Social Benchmarking, Policy-making and the Instruments of New Governance in the EU", Paper presented at European Community Studies Association Conference, Madison, Wisconsin, May 31 -June 2, 2001.

Dryzek, J. "Complexity and Rationality in Public Life", Political Studies, 35: 424-42, 1987.

Dorf, M., and Sabel C. "A Constitution of Democratic Experimentalism", Columbia Law Review, 1998 (2): 267-473.

Engel, C. „Selbstregulierung im Bereich der Produktverantwortung. Instrumente und deren Ausgestaltung". Preprint of the Max Planck Project Group: Law, Politics and Economics $1998 / 7$.

Falkner, G. "The Council or the social partners? EC social policy between diplomacy and collective bargaining". Journal of European Public Policy, Vol. 7 (5): 705-24, 2000.

Falkner, G. EU Social Policy in the 1990s: Towards a corporatist policy community. European Public Policy Series. Routledge, London/New York, 1998.

Haufler, V. "Self-Regulation and Business Norms: Political Risk, Political Action". In: Culter, C., Haufler, V. and Porter, T. (eds.), Private Authority and International Affairs, New York: SUNY Press, 1999.

Haas, P. "Epistemic communities and international policy co-ordination", International Organisation 46, pp. 1-35, 1992.

Héritier, A., Knill, C., and Mingers, S. Ringing the Changes in Europe: Regulatory Competition and the Transformation of the State: Britain, France and Germany. Berlin: de Gruyter, 1996.

Héritier, A. "Elements of Democratic Legitimation in Europe: an Alternative Perspective". Journal of European Public Policy 1999 6(2), 269-82.

Jacobsson, K., "Employment and Social Policy Coordination. A New System of EU Governance". Paper for the Scancor workshop on 'Transnational regulation and the transformation of the states', Stanford 22-23 June 2001. 
Kooiman, J. "Social-Political Governance". In: J. Kooiman (ed.) Modern Governance: New Government-Society Interactions, Sage, London, 1993.

Lévêque, F. Voluntary Approaches Environmental Policy Research Briefs, Nr.1, 1998.

Mayntz, R., and Scharpf, F.W. „Steuerung und Selbstorganisation in Staatsnahen Sektoren”. In: R. Mayntz and F.W. Scharpf (eds.) Gesellschaftliche Selbstregelung und politische Steuerung, Frankfurt am Main: Campus, 1995.

Mosher, J., "Open method of coordination: Functional and political origins", ECSA Review, 13: 3.

OECD, Voluntary Approaches for Environmental Policy. An Assessment, 1999.

Radaelli, C. "Policy Transfer in the European Union; Institutional Isomorphism as a Source of Legitimacy", Governance 13 (1), 2000.

Ronit, K., and Schneider, V. (eds.) Private Organizations, Governance and Global Politics. London: Routledge, 2000.

Scharpf, F. W. Governing in Europe: Effective and Democratic? Oxford: Oxford University Press, 1999.

Scharpf, F.W. Notes Toward a Theory of Multilevel Governing in Europe, MPIfG Discussion Paper 2000/5.

Scott, Colin, "EU Governance as Control: Promoting Effectiveness and Legitimacy?" Paper presented at European Community Studies Association Conference, Madison, Wisconsin, May 31 - June 2, 2001.

Spindler, G. "Recht und Organisationsnormung". Presentation at the Max Planck Project Group: Law, Politics and Economics, November 2000.

Streeck, W. "From Market Making to State Building? Reflections on the Political Economy of European Social Policy". In: Stephan Leibfried and Paul Pierson (eds.), European Social Policy. Between Fragmentation and Integration. Washington, DC: Brookings, 389-431, 1995.

Streeck, W., and Schmitter, P. "Gemeinschaft, Markt und Staat - und die Verbände? ", Journal für Sozialforschung, Bd. 25:2, pp. 133-157, 1985. 
Van Vliet, M. "Environmental Regulation of Business: Options and Constraints for Communicative Governance". In: J. Kooiman (ed.) Modern Governance: New Government-Society Interactions, Sage, London, 106-18, 1993.

Windhoff-Héritier, A. Politikimplementation - Ziel und Wirklichkeit politischer Entscheidungen. Königstein: Hain Verlag, 1980. 
Author: Adrienne Héritier

Title: "New Modes of Governance in Europe: Policy Making without Legislating?"

Reihe Politikwissenschaft / Political Science Series 81

Editor: Christine Neuhold

Associate Editor: Gertrud Hafner

ISSN: $1605-8003$

(C) 2001 by the Department of Political Science, Institute for Advanced Studies (IHS),

Stumpergasse 56, A-1060 Vienna • 푱 +43 1 59991-0 • Fax +43 $15970635 \bullet$ http://www.ihs.ac.at 